\title{
Comparison of Clinic - Histopathologic Findings and Morphometric Measurements of Subclinical Laminitic Claws in Dairy Cattle
}

\author{
Göksen Çeçen Ayalp ${ }^{1}$, Gülsüm Ülke Çalışkan ${ }^{2 *}$, Aylin Alasonyalılar Demirer ${ }^{3}$ \\ ${ }^{I}$ Department of Surgery, Veterinary Faculty, Uludă̆ University, 16059 Bursa, Turkey \\ ${ }^{2}$ Veterinary Department, Ihsangazi Vocational School of Higher Education, Kastamonu University, 37250 Kastamonu, Turkey \\ ${ }^{3}$ Department of Pathology, Veterinary Faculty, Uludağ University, 16059 Bursa, Turkey
}

*Corresponding author

\begin{tabular}{l|l} 
A R T I C L E I N F O & A B S T R A C T \\
$\begin{array}{l}\text { Research Article } \\
\text { Received : 12/09/2018 }\end{array}$ & $\begin{array}{l}\text { The aim of this study was to evaluate the clinic-histopathologic characteristics and to compare the } \\
\text { morphometric measurements of healthy and subclinical laminitic claws of dairy cattle at different } \\
\text { ages and weights. Non-lame 60 Holstein feet randomly collected from the slaughterhouse were } \\
\text { evaluated. The effects of age, body-weight, claw location (right front lateal or right front medial } \\
\text { etc), and presence of laminitis were investigated. The claws' conformation were evaluated } \\
\text { morphometrically with ten measurements (toe length, toe height, outer and inner edges of the claw, } \\
\text { heel height, the length of heel, the length of diagonal front wall, dorsal hoof angle, the width and the } \\
\text { length of the sole). The claws were classified as normal or laminitic according to the histopathologic } \\
\text { findings. The clinical findings of laminitis was confirmed on 71.2\% of the claws (n=66). The toe } \\
\text { length, toe height, the height of outer and inner edges of the claw, heel height, the length of heel, the } \\
\text { length of diagonal front wall were smaller in laminitic claws. The dorsal hoof angle of healthy claws } \\
\text { were bigger and statistically significant than the laminitic claws. Small haemorrhagic areas were } \\
\text { determined in the parietal corium in the laminitic claws comparing to macroscopically healthy } \\
\text { claws. The histopathologic characteristics of the corium of laminitic claws involve the hyperaemia, } \\
\text { haemorrhages, oedema, thrombosis of capillaries and presence of mononuclear cell infiltration in } \\
\text { dermis, stretching epidermal lamella, necrosis of epithelial cells and detachment of the lamellar } \\
\text { basement membrane. According to this study results, contrary to literature, there was not a reliable } \\
\text { relation between some changes in morphological structure of the claws and the presence of the } \\
\text { laminitis were observed. }\end{array}$ \\
$\begin{array}{l}\text { Keywords: } \\
\text { Claw conformation } \\
\text { Laminitis } \\
\text { Morphometric measurements } \\
\text { Histopathology of cow claws }\end{array}$ \\
\hline
\end{tabular}

\section{Introduction}

Lameness is one of the most important economically problems especially for the modern dairy units. It could cause serious losses such as infertility and mastitis (Yurdakul, 2018). One of the most common cause of lameness in dairy cattle is laminitis (Belge, 2015).

Laminitis is the most common disease of the hoof in dairy cattle, a diffuse aseptic inflammation of the hoof wall laminar corium and also includes the sole corium (Greenough, 2007). Subclinical form of laminitis refers to an insidious problem (Nocek, 1997) and it produces physical changes and claw-horn abnormalities in the hoof (Belge, 2005; Desrochers, 2013).

Claw quality has been defined as the product of horn characteristics, claw shape and the anatomy and physiology of inner structure (Politiek et al., 1986; Vermunt and Greenough, 1995). The clinical importance of claw conformation in cattle is considered with particular reference to lameness, longevity and production traits. And relationships have been found between claw measurements and claw disorders, also production traits and sustainability. For this reason, accurate and reproducible measurement methods must be used for qualitative evaluations (Vermunt and Greenough, 1995).

The standard measurements of a normal and healthy hoof have been well described (Shearer and van Amstel, 2001; Nuss and Paulus, 2006; Greenough, 2007). The most commonly measured traits to describe claw conformation in cattle include the dorsal angle, toe length, heel height, claw width, claw length, toe-heel ratio, diagonal length and sole area (Vermunt and Greenough, 1995). However, there is less information about hoof measurements and their relationships in claw disorders (Olechnowicz and Jaskowski, 2010).

The aim of the study was to evaluate the clinicalhistopathological characteristics and morphometric measurements of claw conformation, at different ages and weights, not only healthy claws but also with subclinical laminitic claws of dairy cattle. 


\section{Materials and Methods}

In this study, 480 claws of sixty feet of Holstein dairy cattle were evaluated. Age distribution was between 1- 7 years $(3.53 \pm 1.76)$ and live weights distribution was between $230-550 \mathrm{~kg}(394.75 \pm 56.68)$. The claws were obtained from a slaughterhouse in Bursa (Turkey), randomly. The attention has been given for the selected animals not to be lame by visual inspection before slaughter. The selected feet were transferred to Uludağ University Faculty of Veterinary Medicine Department of Surgery Clinics. The cleaning and measurements of claws were made in terms of centimeters $(\mathrm{cm})$ from different points (Figure 1) (Vermunt and Greenough, 1995): toe length from coronary band to the toe tip (A), toe height from coronary band in the toe region to the ground level, the height of outer (B) and inner edges (C); heel height from coronary band in heel region to the ground level (D), the length of heel $(\mathrm{E})$, the length of diagonal front wall $(\mathrm{F})$ (paries ungulae), dorsal hoof angle $\left({ }^{\circ}\right)$ between dorsal hoof wall and sole lines by a protractor $(\mathrm{G})$, the width of the sole $(\mathrm{H})$, the length of the sole (I). All such measurements, except for toe angle, were made using a flexible tape measure directly from the hoof. A goniometer was used for measuring the toe angle. All measurements were made by the same researchers (Cecen GA., Caliskan GU.) and repeated twice.

In the macroscopic examination, the localisations and shapes of each claws were recorded. Besides, soles of the claws were evaluated for imbibition areas, white line defects, crumbling and discolorations. The presence of obvious haemorrhage was recorded in all claws after the horn tissue (capsula ungulae) was removed as reported previously (Ossent and Lischer, 1997). The claws were cut into perpendicular segments using autopsy saw and the samples taken from different regions (walls, heel, sole and white line) for histopathological examination. The samples fixed in $10 \%$ neutral buffered formalin minimum 24 hours. Then claws subsequently treated with a decalcification solution. Decalcified specimens were treated with graded alcohol, xylene, and paraffin, following the routine for histopathological process. Fivemicrometer $(\mu \mathrm{m})$ tissue sections were cut and stained with Haematoxylin and Eosin (H\&E) (Merck, Germany). Histopathologically, various characteristics such as stretching and tapering at the tips of epidermal lamellae, shape and chromatin density changes in epidermal basal cells, detachment of the lamellar basement membrane, necrosis of epithelial cells, hyperaemia, haemorrhage, thrombosis of capillaries, oedema in dermal lamellae and presence of mononuclear cell infiltration in dermis was evaluated as laminitis. Laminitis was graded according to severity of the inflammatory lesion as mild, moderate or severe.

The cattle were divided as healthy [ 34 cows; $n=272$ claws, Group I (G I)] and subclinical laminitic [26 cows, $\mathrm{n}=208$ claws, Group II (G II) and Group III (G III)] according to histopathological findings. The cattle suffering from laminitis were also distributed into two groups as clinically affected claws from laminitis $(n=66$ in G II) and clinically unaffected claws from laminitis ( $n=142$ in G III) of the same animal.
SPSS software (ver. 13.0, SPSS, USA) was used to perform the statistical analysis. Continuous variables are expressed as the mean \pm standard deviation (SD). P values $<0.05$ were considered as significant.
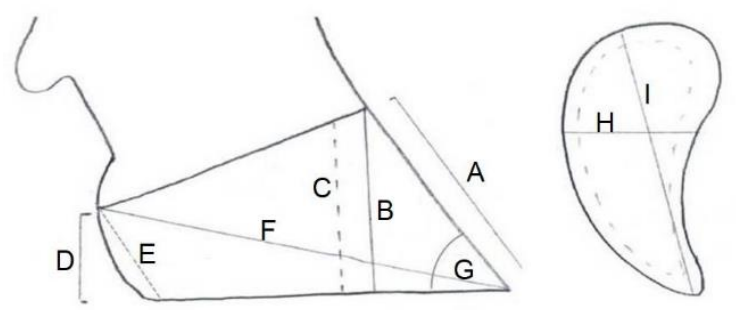

Figure 1 Schematic view of the values, morphometric measurements, on the cows claws

Toe length from coronary band to the toe tip (A), toe height from coronary band in the toe region to the ground level, the height of outer (B) and inner edges (C) of the claw; heel height from coronary band in heel region to the ground level (D), the length of heel (E), the length of diagonal front wall (F) (paries ungulae), dorsal hoof angle $\left(^{\circ}\right.$ ) measured between dorsal hoof wall and sole lines by a protractor $(\mathrm{G})$, the width of the sole $(\mathrm{H})$, the length of the sole (I)

\section{Results}

In this study, non-lame Holstein feet $(n=60)$ randomly collected from the slaughterhouse were evaluated. According to the groups (G I-II-III) the average age and body weight of cows are presented in Table 1.

According to findings of the histopathological evaluation, in healthy cases, the connection between the dermal lamella-epidermal lamellae and the epidermal lamella-basal membrane were fairly tight and at the tips of the epidermal lamella had round shape (Figure 2A).

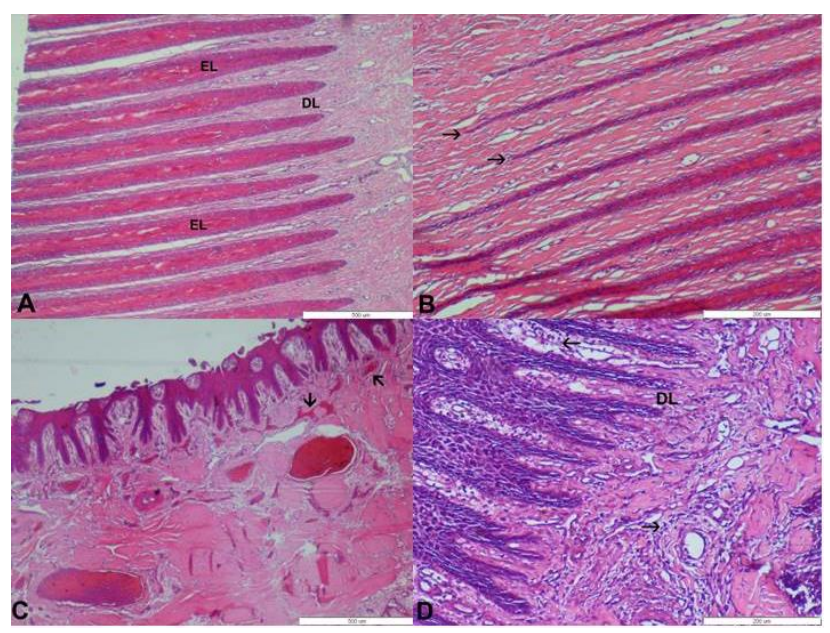

Figure 2 Sections of the lamellar layer of claws 2A. The appearance of epidermal (EL) and dermal lamellae (DL) from healthy claw, (RFM). The connection between EL and DL was tight and the EL had round shape, bar: $500 \mu \mathrm{m}, \mathrm{H} \& \mathrm{E}$ stain; 2B. Arrows depict stretching and tapering of EL in the laminitic claw (RHL) bar: $200 \mu \mathrm{m}$, $\mathrm{H} \& \mathrm{E}$ stain; 2C. Arrows depict hyperaemia of capillaries in laminitic

claw (LFL) bar: $500 \mu \mathrm{m}, \mathrm{H} \& \mathrm{E}$ stain; 2D. Arrows depict severe mononuclear cell infiltration in DL of the laminitic claw (RHL). bar: $200 \mu \mathrm{m}, \mathrm{H} \& \mathrm{E}$ stain. RFL: The lateral claw of the right front foot; RFM: The medial claw of the right front foot; LFL: The lateral claw of the left front foot; LFM: The medial claw of the left front foot; RHL: The lateral claw of the right hind foot; RHM: The medial claw of the right hind foot; LHL: The lateral claw of the left hind foot; LHM: The medial claw of the left hind foot 
Table 1 The age distribution and the age (year) and weight $(\mathrm{kg})$ average of animal in all groups of the study

\begin{tabular}{ll|cccccccc}
\hline \multirow{2}{*}{ Groups } & \multicolumn{6}{c}{ Age distribution* } & \multirow{2}{*}{ Average age (year) } & Average weight (kg) \\
\cline { 3 - 7 } & 1 & 2 & 3 & 4 & 5 & $\geq 6$ & & $3.32 \pm 1.7$ & $395.29 \pm 60.2$ \\
\hline G I & $(\mathrm{n}=272)$ & 8 & 4 & 7 & 5 & 5 & 5 & $3.42 \pm 1.7$ & $388.18 \pm 51.7$ \\
\hline G II & $\begin{array}{l}(\mathrm{n}=66) \\
\text { G III }\end{array}$ & $(\mathrm{n}=142)$ & 2 & 6 & 3 & 5 & 5 & 5 & \\
\hline
\end{tabular}

* The number of cows in each age column; G I: group of healthy cows (34 cows; $n=272$ claws); G II - G III: The cows suffering from laminitis (26 cows, $n=208$ claws): $\mathrm{G} \mathrm{II}(\mathrm{n}=66)$ affected claws from laminitis and G III $(\mathrm{n}=142)$ unaffected claws from laminitis of the same animal

Table 2 The severity of the laminitis and distribution of claws in G II ( $\mathrm{n}=66$ ) according to the histopathological findings

\begin{tabular}{l|cccccccc}
\hline \multirow{2}{*}{ Laminitis degree } & \multicolumn{10}{c}{ Affected claws (n) } \\
\cline { 2 - 9 } & RFL & RFM & LFL & LFM & RHL & RHM & LHL & LHM \\
\hline Mild & 5 & 3 & 6 & 10 & 7 & 2 & 7 & 6 \\
Moderate & 2 & 1 & 2 & 1 & 3 & 3 & 4 & 2 \\
Severe & - & - & - & - & 1 & - & 1 & - \\
Total & 7 & 4 & 8 & 11 & 11 & 5 & 12 & 8 \\
\hline
\end{tabular}

RFL: The lateral claw of the right front foot; RFM: The medial claw of the right front foot; LFL: The lateral claw of the left front foot; LFM: The medial claw of the left front foot; RHL: The lateral claw of the right hind foot; RHM: The medial claw of the right hind foot; LHL: The lateral claw of the left hind foot; LHM: The medial claw of the left hind foot

Table 3 The evaluation of measurements $(\mathrm{cm})$ on the claws (means $\pm \mathrm{SD}$ )

\begin{tabular}{l|ccc}
\hline \multirow{2}{*}{ Measurements } & \multicolumn{3}{c}{ Groups (I - III) } \\
\cline { 2 - 4 } & G I & G II & G III \\
\hline A & $8.5 \pm 1.2^{\mathrm{b}}$ & $8.8 \pm 1.3^{\mathrm{a}} \pm 1.3^{\mathrm{a}}$ \\
$\mathrm{B}$ & $7.8 \pm 0.9^{\mathrm{c}}$ & $8.0 \pm 1.0^{\mathrm{a}}$ & $8.4 \pm 5.9^{\mathrm{b}}$ \\
$\mathrm{C}$ & $5.5 \pm 0.8^{\mathrm{c}}$ & $5.1 \pm 0.6^{\mathrm{a}}$ & $5.3 \pm 0.7^{\mathrm{b}}$ \\
$\mathrm{D}$ & $3.9 \pm 0.8^{\mathrm{b}}$ & $4.3 \pm 1.1^{\mathrm{a}}$ & $4.3 \pm 1.4^{\mathrm{a}}$ \\
$\mathrm{E}$ & $5.1 \pm 1.1^{\mathrm{b}}$ & $5.8 \pm 0.7^{\mathrm{a}}$ & $5.8 \pm 0.6^{\mathrm{a}}$ \\
$\mathrm{F}$ & $15.8 \pm 1.9^{\mathrm{b}}$ & $16.6 \pm 2.3^{\mathrm{a}}$ & $16.5 \pm 2.0^{\mathrm{a}}$ \\
$\mathrm{G}$ & $42.9 \pm 6.4^{\mathrm{b}}$ & $40.4 \pm 6.7^{\mathrm{a}}$ & $41.3 \pm 5.9^{\mathrm{a}}$ \\
$\mathrm{H}$ & $5.1 \pm 0.9^{\mathrm{a}}$ & $5.2 \pm 0.7^{\mathrm{a}}$ & $5.5 \pm 4.5^{\mathrm{a}}$ \\
I & $11.2 \pm 1.8^{\mathrm{a}}$ & $11.6 \pm 2.1^{\mathrm{a}}$ & $11.6 \pm 1.8^{\mathrm{a}}$ \\
\hline
\end{tabular}

${ }^{\mathrm{a}-\mathrm{b}-\mathrm{c}}$ There was no significant difference between measurements on the same line indicated by the same characters (P>0.05). There was a statistically significant difference between the measurements with different superscript characters on the same line $(\mathrm{P}<0.05)$. $((\mathrm{A})$ toe length from coronary band to the toe tip; (B) toe height from coronary band in the region to the ground level the height of outer and inner edges; (C) of the claw; (D) heel height from coronary band in heel region to the ground level; (E) the length of heel; (F) the length of diagonal front wall; (G) dorsal hoof angle $\left({ }^{\circ}\right)$ measured between dorsal hoof wall and sole lines by a protractor; $(\mathrm{H})$ the width of the sole; (I) the length of the sole)

Non-cornified epidermal lamellas consisted of several cell layers were seen. Despite that, in laminitis cases, tapering at the tips of epidermal lamellae was observed and had only 1 or 2 cell thick. Morphological changes, degeneration and necrosis were observed in epidermal basal cells. Haemorrhagea, oedema, thrombosis of capillaries, and inflammatory cells around tissue were seen in some laminitis cases.

Inflammation scoring for laminitic claws (G II) was based on presence of lesions like detachment of the lamellar basement membrane, stretching and tapering of epidermal lamella (Figure 2B), vascular changes like hyperaemia (Figure 2C), haemorrhageas, oedema, thrombosis and severity of inflammatory cells in dermal lamellae (Figure 2D). The number of cases according to histopathological scoring are shown in Table 2 . Histopathologically, forty-six mild, eighteen moderate, and two claws were severe laminitis in this study. Laminitis was seen more common in the hind $(n=36)$, left $(n=39)$ and lateral $(n=38)$ claws $(n=30$ in front claws, $n=$ 27 in right claws and $n=28$ in medial claws). For the diagnosis of laminitis, the samples were taken from the front walls and soles of the claws.

The clinical measurements of the claws were presented in the Table 3. The values of the claws in G I were significantly smaller than G II and G III (excluding
$\mathrm{C}, \mathrm{G}$ and I values). The heights of outer (B) and inner edges (C) of the claws were statistically significant between all groups $(\mathrm{P}<0.05)$ (Table 3$)$. The lowest $\mathrm{D}$ value (heel height from coronary band in heel region to the ground level) was recorded in G I. The length of heel (E), the length of diagonal front wall (F) and dorsal hoof angle $(G)$ were recorded very close values in G II and G III, but $E$ and $F$ values were significantly smaller $(\mathrm{P}<0.05)$ and the value of $G$ was significantly greater in $G I$. The morphometric measurements of G II and G III were found significantly different than G I values except the width (H) and the length of the sole (I). In comparison, young (1-4 years) and old animals (ages 5 and up) measurements of the A, C, E, F, H and I values were statistically significant in all groups $(\mathrm{P}<0.05)$. The length of diagonal front wall $(\mathrm{F})$ measurements increased with age in all groups. The D values showed no significant difference between groups $(\mathrm{P}>0.05)$. The value of $\mathrm{D}$ decreased with age in G I, but increased with age in G II and G III. Compared to the front and hind foot claws, statistically significant differences were determined in measurements except $\mathrm{A}$ and $\mathrm{B}$ values in all groups $(\mathrm{P}<0.05)$. The length of heel (E) values and the heel height (D) and the width of the sole $(\mathrm{H})$ values significant differences were noticed in the comparison of the lateral and medial claws in G III $(\mathrm{P}<0.05)$. In all groups, the measurement of $\mathrm{H}$ value in lateral claws was greater than the medial claws $(\mathrm{P}>0.05)$. 
The length of the sole (I) was similar to in lateral and medial claws in all groups. In groups, the $\mathrm{H}$ and I values of the claws increased with age and were statistically significant $(\mathrm{P}<0.05)$.

The shapes of claws are presented in Table 4 . The rates of claw deformities were found to be as follow: $42.6 \%$ in G I, $28.8 \%$ in G II and $26.0 \%$ in G III.

The soles were evaluated for changes presented in Table 5.

Following the separation of the capsule from corium, the presence of obvious haemorrhageas (Figure 3A-3B) was recorded as $74.2 \%$ in G II, $50.0 \%$ in G III and $2.9 \%$ in G I. The majority of haemorrhagea was focal and localized in parietal corium (Figure 3A). The rates of focal haemorrhageas were found as follow: $69.3 \%$ in G II, $63.3 \%$ in G III and $50.0 \%$ in G I. There were no significant differences according to the location of the claw (front / hind or right / left leg or lateral / medial) $(\mathrm{P}>0.05)$.

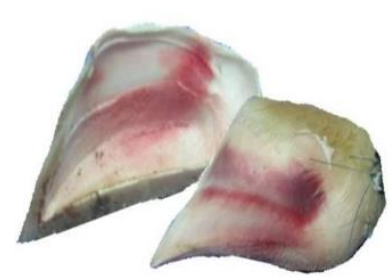

3A Focal hemorrhage in parietal corium (Case No. 51 - LFL in G1)

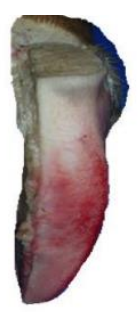

3B Diffuse hemorrhage in solea

(Case No. 2 - LFM in G2)

Figure 3 Macroscopic findings following the separation of the capsule from corium

3A. Focal haemorrhagea in parietal corium (G III - case No.8; The lateral claw of the left hind foot); 3B.Diffuse haemorrhagea in solea and parietal corium (G II - case No.9; The medial claw of the left front foot)

Table 4 Distributions of claw deformities of groups

\begin{tabular}{|c|c|c|c|c|}
\hline \multirow{2}{*}{ Deformities of Claws } & \multicolumn{3}{|c|}{ Groups (I - III) } & \multirow{2}{*}{ Total $[\mathrm{n}-(\%)]$} \\
\hline & G I & G II & G III & \\
\hline Undeformed claws $[\mathrm{n}-(\%)]$ & $156-(57.4)$ & $47-(71.2)$ & $105-(73.9)$ & $308-(64.2)$ \\
\hline Deformed claws [n-(\%)] & $116-(42.6)$ & $19-(28.8)$ & $37-(26.0)$ & $172-(35.8)$ \\
\hline Sharp claws $[\mathrm{n}-(\%)]$ & $16-(13.8)$ & - & $8-(21.6)$ & $24-(13.9)$ \\
\hline Blunt claws $[\mathrm{n}-(\%)]$ & $17-(14.6)$ & $1-(5.2)$ & $1-(2.7)$ & $19-(11.0)$ \\
\hline Flat and plump claws $[\mathrm{n}-(\%)]$ & $17-(14.6)$ & $5-(26.3)$ & $2-(5.4)$ & $24-(13.9)$ \\
\hline Crossed claws $[\mathrm{n}-(\%)]$ & $20-(17.2)$ & $8-(42.1)$ & $9-(24.3)$ & $37-(21.5)$ \\
\hline Double soles $[\mathrm{n}-(\%)]$ & $46-(39.6)$ & $5-(26.3)$ & $17-(45.9)$ & $68-(39.5)$ \\
\hline Total $[\mathrm{n}-(\%)]$ & $272-(56.2)$ & $66-(13.8)$ & $142-(29,6)$ & $480-(100)$ \\
\hline \multicolumn{5}{|c|}{$\begin{array}{l}\text { G I: group of healthy cows ( } 34 \text { cows; } n=272 \text { claws); G II }- \text { G III: The cows suffering from laminitis (26 cows, } n=208 \text { claws): G II (n=66) affecte } \\
\text { claws from laminitis and G III ( } n=142) \text { unaffected claws from laminitis of the same animal }\end{array}$} \\
\hline \multicolumn{5}{|c|}{ Table 5 The distributions of the findings on the horn of the sole } \\
\hline \multirow{2}{*}{ Findings } & \multicolumn{3}{|c|}{ Groups (I - III) [n-(\%)] } & \multirow{2}{*}{ Total $[\mathrm{n}-(\%)]$} \\
\hline & G I & G II & G III & \\
\hline Normal claws $[\mathrm{n}-(\%)]$ & $222-(5.1)$ & $49-(12.2)$ & $132-(32.8)$ & 403 \\
\hline \multirow{5}{*}{$\begin{array}{ll}\text { Subclinic } & \text { Whit } \\
\text { Laminitic } & \text { Crum } \\
\text { Claws } & \text { Disc } \\
& \end{array}$} & $2-(0.7)$ & - & $1-(0.7)$ & $3-(3.9)$ \\
\hline & $2-(0.7)$ & $5-(7.5)$ & $5-(3.5)$ & $12-(15.6)$ \\
\hline & $46-(16.9)$ & $6-(9.0)$ & $2-(1.4)$ & $54-(70.1)$ \\
\hline & - & $6-(9.0)$ & $2-(1.4)$ & $8-(10.4)$ \\
\hline & $272-(56.2)$ & $66-(13.8)$ & $142-(29.6)$ & $480-(100)$ \\
\hline
\end{tabular}

\section{Discussion and Conclusion}

A relationship has been found by the researchers between claw conformation and claw diseases (Vermunt and Greenough, 1995). In the study data showed that except for the width of the sole and the length of the sole, measurements for the subclinical laminitic claws were bigger than healthy claws. In the literatures, the cow claws that have undergone clinical laminitis are reported increase in measurements of toe length, the length of diagonal front wall and the length of the sole. However, the dorsal hoof angle, heel height and the length of heel measurements of claws are decreased (Blowey, 1993; Greenough, 2007).

All feet may not be affected by laminitis (Greenough 2007). In the presented study, 2.8 laminitic claws were recorded for per affected cow (8 claws per cow) and lateral claws were more commonly affected by subclinical laminitis (Table 2). As previously reported (Blowey, 1993; Greenough, 2007), laminitis rate of lateral claws was found higher than medial claws. This process may be associated with the changes in the dynamics inside the claw resulting from traumatic factors in the etiology of laminitis (Mulling and Greenough, 2006).

The results of the research of Mendes et al. (2013) suggested that even in the absence of macroscopic hoof signs associated to laminitis, dairy cows have histological injuries compatible with inflammation of the dermoepidermal junction as in affected animals. The Cows with no clinical signs of hoof abnormalities have inflammation scores and epidermal cell changes similar to laminitis injuries, suggesting the existence of a prodromal phase for this disease in bovines (Mendes et al., 2013). In the current study, there were histopathological changes in absence of clinical signs in 26 cows. Subclinical laminitis has been determined with high incidence $(60$ cows, $43.3 \%$ ) according to histopathological assessments.

The histopathologic characteristics of laminitis were determined as compatible with the existed literature such as the stretching of epidermal lamellae, hyperaemia, 
dermal oedema, haemorrhage, changes in basal cell morphology, mononuclear cell infiltration in dermis, and signs of basement membrane detachment (Maclean, 1971; Nocek, 1997; Thoefner et al., 2005; Danscher et al., 2010). Infiltrating leukocytes were found in the dermis of all cows in G II, and $69.6 \%$ of them had a mild laminitis score. Even leukocyte infiltration was found in a much lower intensity is an evidence of laminitis in contrast with the literature (Thoefner et al., 2005). The samples taken for histopathological diagnosis from front wall and sole the most appropriate for detecting the presence of the laminitis. The heel tissue more covered with stratified squamous epithelium instead of the lamellar epithelium (Maclean, 1971). Therefore, samples taken from the heel region cannot be used alone for confirmatory histopathological diagnosis of laminitis.

The flat and plump claws reported with laminitis, which are revealed in the second phase of disease (Greenough, 2007). According to the findings of the presented study, the rate of claw deformations in healthy cows $(n=17)$ was higher than subclinical laminitic cows $(\mathrm{n}=5$ in GII, $\mathrm{n}=2$ in G III). However the flat and plump claw deformities rates were found significantly higher in subclinical laminitic claws $(\mathrm{P}<0.05)$. It means that this deformation type may be interpreted as a sign of the laminitis.

Many researchers have suggested an association between subclinical laminitis and hoof lesions such as white line disease, haemorrhage of the sole, erosion of the heel, yellow discoloration of the sole (Bradley et al., 1989; Logue, 1995; Belge, 2005), double sole and sole ulcers (Bradley et al., 1989; Logue, 1995). Sole haemorrhage and double sole findings in the present study were not compatible with the findings of literature. The double sole formation was seen in a low rate $(26.3 \%, 5$ cases in 19 laminitis claws in G II) (Table 4). And sole haemorrhagea was not seen in subclinical laminitic claws.

In this study, following the separation of the capsule from corium, the majority of haemorrhage was seen as focal and localized in the parietal corium. In the earlier stages of subclinical laminitis the corium of the wall regions is reddened. It is important to know that there are no overt clinical signs at this stage (Ossent and Lischer, 1998).

In conclusion, the obtained data showed that there was not a reliable relation between the presence of the subclinical laminitis and some changes in morphologic structure of the bovine claws. Many changes in the hoof were recognized on gross examination but the cows might have dermal changes in the hoof even in the absence of any macroscopic signs of subclinical laminitis.

\section{Acknowledgements}

This work was supported by The Scientific and Technological Research Council of Turkey under Grant [number 1070817]. The authors are thankful to Ender CARKUNGOZ UZABACI (Research Assistant in Uludag University, Veterinary Faculty, and Department of Biometrics) for statistic evaluations.

\section{References}

Belge A, Akın İ. 2015. Subclinical laminitis in dairy cows: Predisposing factors. Turkiye Klinikleri J Vet Sci SurgSpecial Topics. 1: 32-37.

Belge A, Bakir B, Gönenci R, Ormanc1 S. 2005. Subclinical laminitis in dairy cattle: 205 selected cases. Turk J Vet Anim Sci.; 29: 9-15.

Blowey R. 1993. Common diseases of the foot. In: (Ed; Blowey R.). Cattle Lameness and Hoof Care: An Illustrated Guide. Farming Press, Ipswich, UK. pp. 3-21.

Bradley HK, Shannon D, Neilson DR. 1989. Subclinical laminitis in dairy heifers. Vet Rec. 125: 177-179.

Danscher AM, Toelboell TH, Wattle O. 2010. Biomechanics and histology of bovine claw suspensory tissue in early acute laminitis. J Dairy Sci. 93: 53-62.

Desrochers A. 2013. Non-Infectious lameness (In Session VI. Digital Dermatitis and Lameness) Western Canadian Dairy Seminar (WCDS) Advances in Dairy Technology, Canada, pp. 255-266. Available from: https://wcds.ualberta.ca/ Proceedings/Previous-Proceedings/ArticleID/561/2013 [Accessed 15.06.2015].

Greenough PR. 2007. Bovine Laminitis and Lameness: A Hands-On Approach. 1st Ed., Saunders/Elsevier, Toronto, Canada.

Logue D. 1995. Lameness, lesions of the claw of the dairy cow and subclinical laminitis. Brit Vet J. 151: 343-346.

Maclean CW. 1971. The histopathology of laminitis in dairy cows. J Comp Pathol. 81: 563-570.

Mendes HMF, Casagrande FP, Lima IR, Souza CH, Gontijo LD, Alves GES, Vasconcelos AC, Faleiros RR. 2013. Histopathology of dairy cows' hooves with signs of naturally acquired laminitis. Pesquisa Vet Brasil. 33 (5): 613-619.

Mulling CKW, Greenough PR. 2006. Applied physiopathology of the foot. Available from: http://www.ivis.org [Accessed 05.07.2015].

Nocek JE. 1997. Bovine asidosis: Implications on laminitis. J Dairy Sci. 80: 1005-1028.

Nuss K, Paulus N. 2006. Measurements of claw dimensions in cows before and after functional trimming: A post-mortem study. Vet J. 172: 284-292.

Olechnowicz J, Jaskowski JM. 2010. Hoof measurements related to locomotion scores and claw disorders in dairy primiparous cows. B Vet I Pulawy. 54: 87-92.

Ossent P, Lischer C. 1997. Post mortem examination of the hooves of cattle, horses, pigs and small ruminants under practice conditions. In Pract. 19 (1): 21-28.

Ossent P, Lischer C. 1998. Bovine laminitis: the lesions and their pathogenesis. In Prac. 20 (8): 415-427.

Politiek RD, Distl O, Fjeldaas T, Heeres J, Mcdaniel BT, Nielsen E, Peterse DJ, Reurink A, Strandberg P. 1986. Importance of claw quality in cattle: Review and recommendations to achieve genetic improvement. Report of the E.A.A.P. Working Group on "Claw Quality in Cattle". Livest Prod Sci. 15: 133-152.

Shearer JK, van Amstel SR. 2001. Functional and corrective claw trimming. Vet Clin N Am-Food A. 17: 53-72.

Thoefner MB, Wattle O, Pollitt CC, French KR, Nielsen SS. 2005. Histopathology of oligofructose-induced acute laminitis in heifers. J Dairy Sci. 88: 2774-2782.

Vermunt JJ, Greenough PR. 1995. Structural characteristics of the bovine claw: Horn growth and wear, horn hardness and claw conformation. Br Vet J. 151: 157-180.

Yurdakul İ, Şen İ. 2018. Investigation of prevalance of foot diseases in the cattle in the region of Sivas. Harran University Journal of the Faculty of Veterinary Medicine. 7: $51-55$. 